\title{
ÖKOLÓGIAI TERMESZTÉSBEN ALKALMAZHATÓ TALAJTAKARÁSI MÓDOK GYOMELNYOMÓ HATÁSA SZAMÓCAÜLTETVÉNYBEN
}

\author{
Király Ildikó - Maczkó Márton - Palkovics András - Mihálka Virág
}

\begin{abstract}
Absztrakt: Az ökológiai gazdálkodás legfontosabb eleme a talaj termékenységének megörzése. Ennek érdekében környezetkímélő talajmüvelést kell folytatni, melynek egyik módja a talajtakarás szerves vagy szervetlen anyagokkal. Kísérletünkben háromféle talajtakarási mód (agroszövet, szalma, széna) gyomelnyomó hatását értékeltük. Mindhárom alkalmazott talajtakarási mód jelentösen csökkentette a gyomtömeget a takaratlan kontroll parcellához viszonyítva. A legnagyobb gyomelnyomó hatása az agroszövetnek volt, viszont ez a talajtakarási mód nehezítette a kísérletben alkalmazott (szerves eredetủ trágyaféleségek adagolása 2 havonta) tápanyag-visszapótlási módot.
\end{abstract}

Abstract: The most important part of the organic farming is the preservation of the soil fertility. For this purpose, environmentally friendly tillage must be carried out, of which one way is using the mulching system with organic or inorganic materials. In our experiment weed-suppressing effect of three different mulching systems (black geotextil, straw, hay) were evaluated. All of the applied mulching systems significantly reduced the weed weight compared to the uncovered control parcel. The black geotextil had the greatest weed-suppressing effect, but this type of soil covering method made more difficult the application of fertilization (dosage of organic manure in every two months).

Kulcsszavak: gyomirtás, talajtakarás, szamóca

Keywords: weed control, mulch, strawberry

\section{Bevezetés}

2015-ben a világon a teljes mezőgazdasági terület 1,1\%-án (50 919006 hektáron) folyt ökológiai gazdálkodás, ebből 5985 ha-on termesztettek szamócát (WillerLernoud, 2017). Az ökológiai szamócatermesztés sikerességének egyik alapja a jó fajtaválasztás, amelyekkel szemben alapkövetelmény a talajbetegségekkel szembeni jó ellenállóképesség, a megfelelő terméshozam, továbbá kiemelkedő fontosságú a gyümölcsök íze is. Mivel az ökológiai gazdálkodás legfontosabb eleme a talaj termékenységének megörzése, a termesztés sikerességét a fajtamegválasztáson túl nagyban befolyásolja az alkalmazott termesztéstechnológia, melyek közül kiemelendő a talajerő-gazdálkodás (talajművelés, tápanyag-utánpótlás, öntözés). Az ökológiai szamócatermesztésben a 2-3 évig fenntartott ültetvényeket elönyben részesítik az egyéves technológiával szemben. A többéves technológia viszont több (növényvédelmi, talajtani) problémát vethet fel.

A talajkímélő talajmüvelési módok között kiemelt jelentősége van a különböző talajtakarási módoknak, melyek talajvédelmi, de akár növényegészségügyi szempontból is kedvezőek lehetnek (Hammermeister, 2016). Talajtakarásra élö növényzet, elhalt növényi maradványok (pl. szalma, fükaszálék, komposzt stb.) és ipari eredetü anyagok (pl. fekete polietilén fólia, agroszövet, papír stb.) anyagok használhatók fel. A szerves takaróanyag tápanyag-szolgáltató képességgel is rendelkezik és fokozza a talajéletet. 
A takaróanyagnak közvetlen hatása van többek között a talaj hőmérsékletére és nedvességtartalmára és a gyomosodásra (Daugaard, 2008; Forcella et al., 2003; Godin et al., 2006; Hammermeister, 2016; Kivijärvi, 2006Ł Kumar-Dey 2011). A különböző talajtakaró anyagok befolyásolhatják a szamóca vegetatív és generatív paramétereit (pl. terméshozam, gyümölcsminöség, tárolhatóság), és a növények egészségi állapotát, mint pl. a fertőzött (pl. szürkepenészes) gyümölcsök elöfordulásának gyakoriságát, vagy a káros, illetve hasznos rovarok felszaporodását (Király et al., 2016; Kivijärvi et al., 2002; Touvinen et al., 2006).

Kísérletünkben háromféle talajtakarási mód (agroszövet, szalma, széna) gyomelnyomó hatását értékeltük.

\section{Anyag és módszer}

\subsection{A vizsgálatok körülményei}

A vizsgálatokat a Neumann János Egyetem, Kertészeti és Vidékfejlesztési Karának (a Kecskeméti Főiskola, Kertészeti Főiskolai Karának jogutódja) tankertjében végeztük két független (2016 és 2017 tavaszán telepített) parcellán.

Az egyik ültetvényt 2016 március végén létesítettük 'Joly' és 'Asia' fajtákkal, a másik ültetvény 2017 március végén került telepítésre 'Olympia' fajta használatával. Mindkét évben frigó palántákat telepítettünk síkmüvelésü ikersoros elrendezésben, $40+70 \mathrm{~cm}$ x $30 \mathrm{~cm}$ térállásra. Az olasz importból származó frigó palánták 'Asia' esetében A+ (rizóma átmérő: 12-15 mm), 'Joly' esetében A (rizóma átmérő: 9-13 $\mathrm{mm}$ ), 'Olympia' esetében pedig A++ (rizóma átmérő: 14-15+ mm) kategóriájúak voltak.

A telepítés elött elvégzett talajanalízis alapján az itt található homoktalaj nitrogén- és káliumszolgáltató képessége gyenge, $\mathrm{pH}$-ja enyhén lúgos, humusztartalma alacsony. Ökológiai jellegü gazdálkodást alkalmaztunk a kísérleti területen, így csak az ökológiai gazdálkodásban felhasználható termésnövelő anyagokat használtunk fel. A telepítés évében további tápanyag kijuttatásra csak a szüret után került sor szerves eredetü trágyaféleségek felhasználásával $\left(200 \mathrm{~g} / \mathrm{m}^{2}\right.$ Greensoil Natural (dudari barnaszén) és $0,4 \mathrm{~kg} / \mathrm{m}^{2}$ Italpollina (pelletált baromfitrágya). Második évben március közepétől, kéthavonta végeztünk tápanyagutánpótlást ( $200 \mathrm{~g} / \mathrm{m}^{2}$ Greensoil Natural és $0,4 \mathrm{~kg} / \mathrm{m}^{2}$ Italpollina). Virágzás kezdetén a szerves eredetű tápanyaggal együtt $40 \mathrm{~g} / \mathrm{m}^{2} \mathrm{~K}_{2} \mathrm{SO}_{4}$ mütrágyát is kijuttatunk mindkét parcellában.

Háromféle talajtakarási módot alkalmaztunk a kontroll (takaratlan) mellett: agroszövet, szalma és széna (1-2. ábra). Az agroszövetet a telepités elött, a szalma és széna takaróanyagot telepítést követően helyeztük ki a területre. A szalma- és a széna-takarást a vegetációban folyamatosan, $\mathrm{kb}$. havonta pótoltuk, hogy állandóan min. 2-3 cm vastag borítást biztosítsunk. A kontroll (takaratlan) területen csak a virágzás és érés időszakában takartuk a talajt szalmával a gyümölcsök talajszemcsével történő szennyeződésének megelőzése érdekében, majd a takarást a szüret után eltávolítottuk. 
1. ábra: Az egyéves szamócaültetvény: a, telepítés után (2017. április 4.); b, a szüret kezdetén (2017. június 1.) (Kecskemét, 2017)
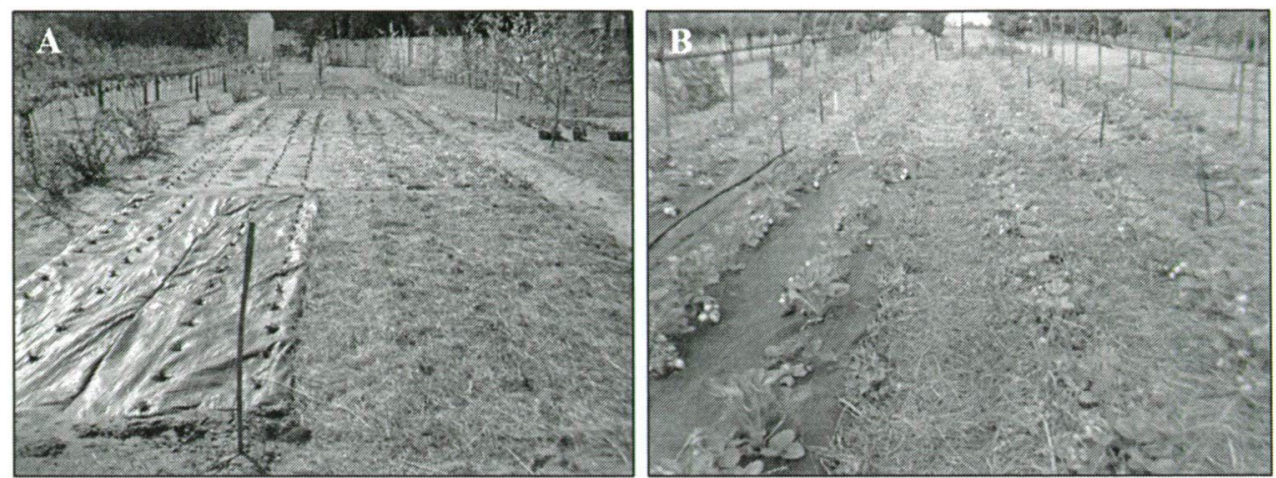

2. ábra: A kétéves szamócaültetvény (2017. április 4.) (Kecskemét, 2017)

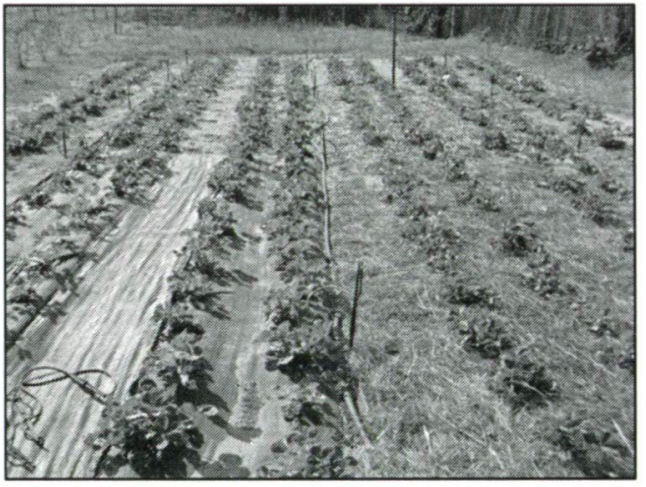

\subsection{Gyomosodás mértékének értékelése}

A gyomosodás mértékét mindkét (2016-ban és 2017-ben létesített) ültetvényben 2017-ben mértük fel. Az adatfelvételezésre 6-7 hetente, összesen 3 időpontban (2017. május 11., június 28., augusztus 14.) került sor a vegetációs időben. A kezelt és kezeletlen parcellákból kézi gyomlálást követően mértük le a friss gyomtömeget. Az adatokat Excel-ben rögzítettük és értékeltük.

A 2017-ben telepített ültetvényben (továbbiakban egyéves ültetvény) a telepítés évében, a 2016-ban telepített ültetvényben (továbbiakban kétéves ültetvény) csak a második vegetációs évben végeztünk felméréseket.

A 2016-ban telepített ültetvényben (kétéves ültetvény) az első évben nem volt lehetőségünk felmérni a gyomosodás mértékét, ennek ellenére a kezelt parcellákon az első évben is folyamatos takarást biztosítottunk, és havonkénti gyomirtást (kézi gyomlálás) végeztünk, tehát az eredmények alapján értékelni tudjuk a tartós (többéves) talajtakarás hatását. 


\section{Eredmények és értékelésük}

Az egy- és kétéves szamócaültetvényekben végzett friss gyomtömeg mérések eredményeit a 3-4. ábrán mutatjuk be. A legnagyobb mértékủ gyomosodást a kontroll (takaratlan) parcellákban kaptuk mindkét ültetvényben. A talajtakarással kapcsolatos szakirodalmakban (Godin et al., 2006; Kivijärvi, 2006; Radics et al., 2006) közöltekhez hasonlóan - mint az várható volt - az agroszövetnek volt a legjobb gyomelnyomó hatása, amit a teljes vegetációban biztosított. A kontrollhoz képest legfeljebb $10 \%$ volt a gyomosodás mértéke.

\section{3. ábra: Az egyéves szamócaültetvényben kezelésenként mért friss} gyomtömegek (g/m²) (Kecskemét, 2017)

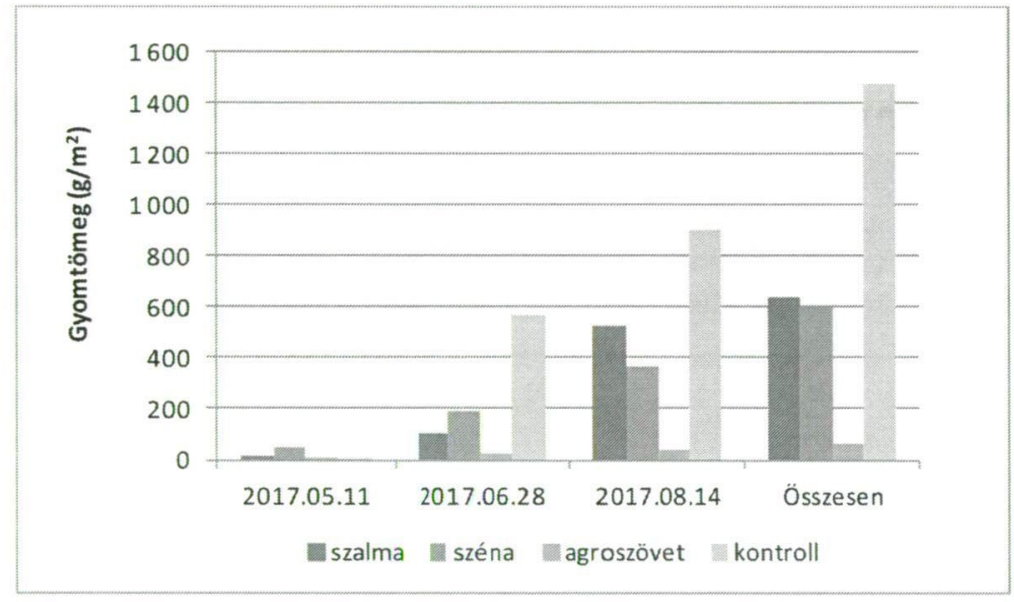

4. ábra: A kétéves szamócaültetvényben kezelésenként mért friss gyomtömegek (g/m2) (Kecskemét, 2017)

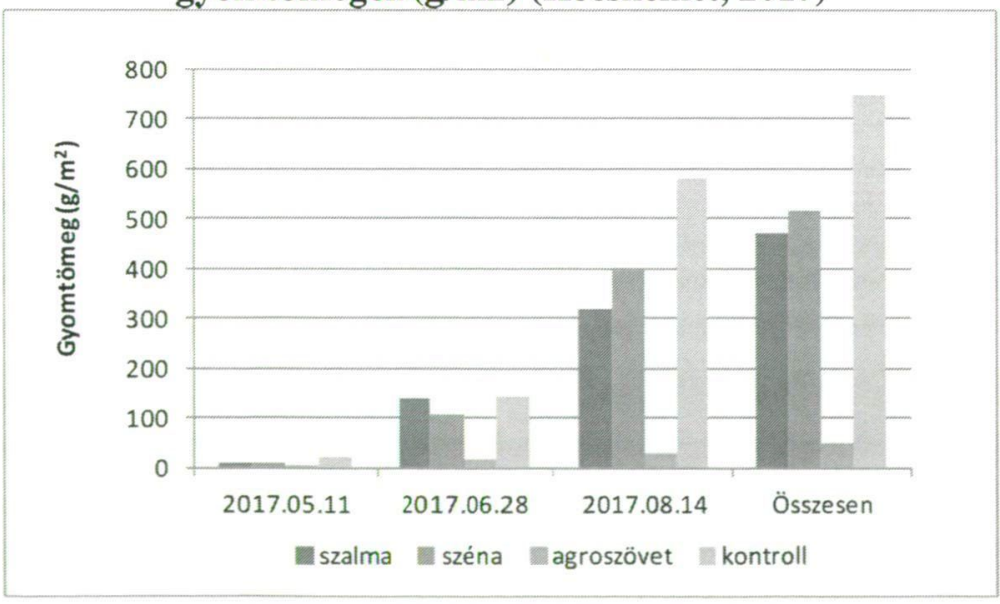

A szalma és széna takaróanyag a kontrollhoz képest 30-60\%-kal csökkentette a gyomosodás mértékét, ami ellentmond a Radics et al. (2006) által paradicsomban 
tapasztaltaknak, mely szerint a kapált parcellák gyomborítottsága kisebb volt, mint a széna, illetve fünyesedékkel takart parcelláké.

Nem találtunk egyirányba mutató gyomelnyomó hatást a szalma-, illetve szénatakarásra vonatkozóan a vegetációs időszak folyamán. Eredményeinkhez hasonlóan Kivijärvi (2006) az alkalmazott talajtakaró anyagok eltérö gyomelnyomó hatását tapasztalta, mely függött a kísérleti parcella gyomösszetételétől is. Kísérletünkben ezt $\mathrm{mi}$ is tapasztaltuk mindkét ültetvényben. $\mathrm{Az}$ egyéves ültetvényben, a tavaszi időszakban 1,5-5-ször nagyobb mértékủ volt a szalmával, illetve szénával takart parcellák gyomosodásának mértéke, mint a kontroll parcelláé (1. táblázat). Ennek oka, hogy a szalma-, de föként a szénatakarásos parcellában jelentős volt az egysziküek (főként tarack és muharfajok) jelenléte. Ezek a vegetáció során folyamatosan kiszorultak a területröl, a harmadik adatfelvételezéskor az egysziküek jelenléte gyakorlatilag megszünt, a kétszikü fajok vették át a helyüket.

A kétéves ültetvényben - a teljes vegetációs időszak összességét tekintve - a kezelt parcellák kontrollhoz viszonyított gyomosodásának mértéke magasabb volt, mint az egyéves ültetvényben (pl. egyéves/szalma: 44\%; kétéves/szalma: 63\%) (1. táblázat). Az arányokat torzítja, hogy az egyéves kontroll parcella igen gyomos volt (a kétéves kontroll percella kétszerese). Ha a kontrollhoz viszonyított arány helyett a friss gyomtömeget vesszük alapul, akkor egyértelmüen látszik, hogy az egyéves ültetvény kezelt parcelláinak gyomtömege magasabb volt.

\section{1. táblázat: A szamócaültetvényekben kezelésenként mért friss gyomtömegek $\left(\mathrm{g} / \mathrm{m}^{2}\right)$, illetve a gyomosodás mértéke $(\%)$ a kontrollhoz viszonyítva} (Kecskemét, 2017)

\begin{tabular}{|c|l|c|c|c|c|c|c|c|c|}
\hline Ültetvény & \multirow{2}{*}{ Kezelés } & \multicolumn{6}{|c|}{ Gyomtömeg/gyomosodás mértéke } \\
\cline { 3 - 10 } & & $\mathbf{2 0 1 7 . 0 5 . 1 1 .}$ & $\mathbf{2 0 1 7 . 0 6 . 2 8 .}$ & $\mathbf{2 0 1 7 . 0 8 . 1 4}$ & \multicolumn{2}{|c|}{ Ősszesen } \\
\cline { 3 - 10 } & & $\mathbf{g} / \mathbf{m}^{\mathbf{2}}$ & $\mathbf{\%}$ & $\mathbf{g} / \mathbf{m}^{\mathbf{2}}$ & $\mathbf{\%}$ & $\mathbf{g} / \mathbf{m}^{\mathbf{2}}$ & $\mathbf{\%}$ & $\mathbf{g} / \mathbf{m}^{\mathbf{2}}$ & $\%$ \\
\hline \multirow{4}{*}{ 1. éves } & szalma & 15 & 165 & 103 & 18 & 524 & 58 & 643 & 44 \\
& széna & 46 & 495 & 190 & 34 & 369 & 41 & 605 & 41 \\
& agroszövet & 1 & 9 & 23 & 4 & 40 & 4 & 64 & 4 \\
& kontroll & 9 & 100 & 565 & 100 & 901 & 100 & 1475 & 100 \\
\hline \multirow{4}{*}{ 2. éves } & szalma & 10 & 45 & 140 & 96 & 322 & 55 & 471 & 63 \\
& széna & 11 & 48 & 108 & 75 & 397 & 68 & 516 & 69 \\
& agroszövet & 2 & 8 & 17 & 11 & 30 & 5 & 48 & 6 \\
& kontroll & 22 & 100 & 145 & 100 & 582 & 100 & 749 & 100 \\
\hline
\end{tabular}

A kétéves ültetvény gyomosodása a teljes vegetációs időszakban 25-50\%-kal enyhébb volt, mint az egyéves ültetvényben. A legnagyobb mértékủ gyomosodást az egyéves ültetvényben a tavaszi, a kétéves ültetvényben pedig a kora nyári adatfelvételezéskor mértük, melynek oka a két ültetvény gyomfaj-összetétele közötti eltérés. Az egyéves ültetvényben a vegetáció elején elsősorban egyszikü fajok, a kétéves ültetvényben pedig kétszikü fajok voltak jelen.

$\mathrm{Az}$ agroszövet gyomelnyomó hatása igen jó, viszont ez a talajtakarási mód nehezítette a kísérletben alkalmazott (szerves eredetü, szilárd halmazállapotú trágyaféleségek adagolása 2 havonta) tápanyag-visszapótlási módot. A szalma- és 
szénatakarás esetében a trágyaféleségeket nem dolgoztuk be, csak a takaróanyag felszínére szórtuk ki, és az öntözövízzel oldottuk fel, illetve mostuk be a gyökérzónába. Tapasztalataink szerint 1-2 héten belül a trágyaféleség „eltünt” a takaróanyag felszínéröl, és - feltételezhetően - a növények rendelkezésre állt.

\section{Következtetések, összegzés, záró megjegyzések, záró gondolatok}

Eddigi eredményeink alapján egyértelmüen látszik a talajtakaró anyagok gyomosodást mérséklő hatása. A gyomelnyomó hatás nagyban függ az alkalmazott takaróanyagtól. A folyamatos talajtakarás befolyásolni tudja az ültetvény gyomflóráját, mérsékli az egyszikü gyomnövények jelenlétét.

$\mathrm{Az}$ agroszövet gyomelnyomó hatása igen jó, viszont nehezíti a szervesanyagutánpótlást. Csak akkor alkalmazható, ha egyéves termesztéstechnológiát alkalmazunk, vagy a tápanyag-utánpótlást nem szilárd, hanem folyékony halmazállapotú trágyaféleséggel oldjuk meg.

Mivel a 2016-os telepítésü (kétéves) ültetvény első évében nem volt lehetőség a gyomtömeg mérésére, a tartós talajtakarás gyomosodást mérséklő hatását a rendelkezésre álló adatok alapján nem tudtuk értékelni, ezért folytatjuk a kísérletet.

\section{Köszönetnyilvánítás}

Köszönettel tartozunk a kutatás támogatásáért, amely az EFOP-3.6.1-16-201600006 „A kutatási potenciál fejlesztése és bővítése a Pallasz Athéné Egyetemen” pályázat keretében valósult meg. A projekt a Magyar Állam és az Európai Unió támogatásával, az Európai Szociális Alap társfinanszírozásával, a Széchenyi 2020 program keretében valósul meg.

Köszönet illeti Jezerniczky Dezsőt a kísérletek kivitelezésében nyújtott segítségért.

\section{Irodalomjegyzék}

Daugaard, H. (2008): The Effect of Mulching Materials on Yield and Berry Quality in Organic Strawberry Production. Biological Agriculture \& Horticulture, 26 (2): 139-147.

Forcella, F., Poppe, S.R., Hansen, N.C., Head, W.A., Hoover, E., Propsom, F., McKensie, J. (2003): Biological Mulches for Managing Weeds in Transplanted Strawberry (Fragaria $\times$ ananassa). Weed Technology, 17 (4): 782-787.

Godin, R., Ela, S., Max, S., Schultz, K., Rohde, J. (2006): Organic Alternatives for Weed Control and Ground Cover Management: Effects on Tree Fruit Growth, Development and Productivity. Agricultural Experiment Station. Technical Bulletin. TB06-03. August 2006. <http://webdoc.agsci.colostate.edu/aes/wcrc/TechBulletins/tb06-3.pdf>. (2016.09.07.)

Hammermeister, A.M. (2016): Organic weed management in perennial fruits. Scientia Horticulturae, 208: $28-42$.

Király I., Palkovics A., Mihálka V. (2016): Különböző talajtakarási módok hatása ökológiai szamóca ültetvényben. Gradus, 3 (2): 344-350.

Kivijärvi, P. (2006): Weed management with different mulches under organic strawberry production. In: NJF Report, Nordic Association of Agricultural Scientists, 2 (10): 35. <http://orgprints.org/10637/1/Lepaa.pdf>. (2016.09.07.)

Kivijärvi, P., Parikka, P., Tuovinen, T. (2002): The effect of different mulches on yield, fruit quality and strawberry mite in organically grown strawberry. In: Organic production of fruit and berries. Nordic Association of Agricultural Scientists. <http://orgprints.org/6188/>. (2016.09.07.) 
Kumar, S., Dey, P. (2011): Effects of different mulches and irrigation methods on root growth, nutrient uptake, water-use efficiency and yield of strawberry. Scientia Horticulturae, 127: 318324.

Radics L., Székelyné E.B., Pusztai P., Horváth K. (2006): Role of mulching in weed control of organic tomato. Zeitschrift für Pflanzenkrankheiten und Pflanzenschutz, 20: 643-650.

Tuovinen, T., Kikas, A., Tolonen, T., Kivijärvi, P. (2006): Organic mulches compared to black plastic in organic strawberry production: effects on ground beetles. NJF seminar No 389: Pest, disease and weed management in strawberry; Finland 8-9. Nov. 2006 In: NJF Report, Nordic Association of Agricultural Scientists, 2 (10): 28.

Willer, H., Lernoud, D. (2017): The World of Organic Agriculture. Statistics and Emerging Trends. Research Institute of Organic Agriculture (FiBL), FRick and IFOAM - Organics International, Bonn. Version $1.3 . \quad$ of $20,2017$. <https://shop.fibl.org/CHde/mwdownloads/download/link/id/785/?ref=1>. (2017.10.23.) 